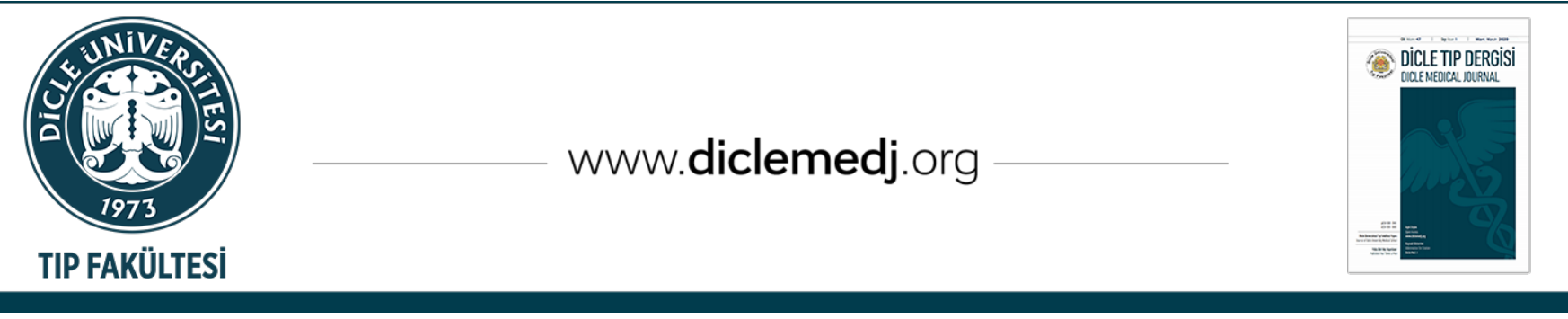

Original Article / Özgün Araştırma

\title{
Can We Predict the Duration of Treatment Requirement by Complete Blood Count in Chronic Spontaneous Urticaria Patients Receiving Omalizumab?
}

\author{
Ebru Celik ${ }^{\text {1D }}$, Emre Dirican ${ }^{2} 2$ \\ 1 Department of Dermatology, Faculty of Medicine, Mustafa Kemal University, Hatay, Turkey \\ 2 Department of Biostatistics, Faculty of Medicine, Hatay Mustafa Kemal University, Hatay, Turkey
}

Received: 16.05.2020; Revised: 17.07.2020; Accepted: 22.07.2020

\begin{abstract}
Objectives: The main assay recommended in chronic urticaria is complete blood count ( $\mathrm{CBC}$ ). It is known that changes in the numerical values and rates of blood cells in the CBC are associated with inflammation and thrombotic risk. In addition, the improvement of some patients with short-term Omalizumab treatment, while others need long-term treatment raises the question of whether this difference can be predicted with parameters on the CBC. This study aimes to evaluate the effect of the drug on CBC parameters in patients with chronic spontaneous urticaria (CSU) receiving Omalizumab treatment.

Methods: The study included 66 patients who received Omalizumab treatment with CSU and 34 healthy individuals as a control group. The values of 17 parameters from the biomarkers in the CBC were recorded in the patient group (before the treatment/after 12 weeks of treatment) and in the control group. In addition, patients with CSU according to the Omalizumab treatment requirement was divided into two groups as those who recovered in a short time ( $\leq 6$ months) (group-1) and those who need longer treatment ( $>6$ months) (group-2). All data were compared statistically.

Results: It was observed that many inflammatory and thrombotic activation markers in the CBC increased in the patient group before treatment compared to the control group, and even most of these values approached the values of healthy individuals after treatment. When the pre-treatment and post-treatment data of the patients are compared within themselves; neutrophil and platelet numbers and neutrophil-monocyte ratio decreased after treatment and there was a statistically significant difference. When the pre-treatment values of the two groups determined according to the treatment requirement period were compared, it was determined that the eosinophil-basophil ratio (EBR) value was significantly higher in the group2 patients. It was observed that the number of platelets in group-1 decreased and eosinophil-lymphocyte ratio and eosinophil-neutrophil ratio increased after treatment compared to pre-treatment; platelet, neutrophil counts and EBR values of patients in group-2 decreased, mean platelet volume (MPV) and platelet distribution width (PDW) values increased.

Conclusion: It has been determined that Omalizumab treatment has positive effects on patients with CSU that it reduces many inflammatory and thrombotic activation markers in CBC. It was thought that an increase in EBR may be a biomarker that predicts that patients with CSU will need Omalizumab treatment for a longer period. In addition, it was concluded that MPV and PDW values increased during Omalizumab treatment of patients with long-term treatment needs, and that thrombotic activation markers of these patients should be followed more closely during the treatment.
\end{abstract}

Keywords: Chronic spontaneous urticaria, Omalizumab, complete blood count, biomarker, thrombotic activation.

\section{DOI: 10.5798/dicletip.799661}

Correspondence / Yazışma Adresi: Ebru Celik, Department of Dermatology, Faculty of Medicine, Hatay Mustafa Kemal University, Hatay, Turkey e-mail: ebruecelik@yahoo.com 


\section{Omalizumab Kullanan Kronik Spontan Ürtiker Hastalarında, Tam Kan Sayımı ile Tedavi Gereksinim Süresini Önceden Tahmin Edebilir miyiz?}

Öz

Amaç: Kronik Ürtiker'de yapılması önerilen temel tetkik tam kan sayımıdır. Tam kan sayımındaki kan hücrelerinin sayısal değerleri ve oranlarındaki değişimin, enflamasyon ve trombotik risk ile ilişki olduğu bilinmektedir. Ayrıca, Omalizumab tedavisi alan bazı hastaların kısa süreli iyileşmesi, bazılarının ise uzun süreli tedaviye ihtiyacının olması, bu farkın tam kan sayımındaki parametrelerle tahmin edilip edilemeyeceği sorusunu gündeme getirmektedir. Bu çalışma, Omalizumab tedavisi alan Kronik Spontan Ürtiker'li (KSÜ) hastalarda ilacın tam kan sayımı parametreleri üzerindeki etkisini değerlendirmeyi amaçlamaktadır.

Yöntemler: Çalışmaya KSÜ tanısıyla Omalizumab tedavisi alan 66 hasta ile kontrol grubu olarak 34 sağlıklı birey dahil edildi. Tam kan sayımında yer alan biyobelirteçlerden 17 adet parametrenin, hasta grubunda (tedavi öncesi/12 haftalık tedavi sonrası) ve kontrol grubundaki değerleri kaydedildi. Ayrıca, KSÜ'lü hastalar omalizumab tedavi gereksinimine göre; kısa sürede ( $\leq 6$ ay) iyileşenler (grup-1) ve daha uzun süre ( $>6$ ay) tedavi ihtiyacı olanlar (grup-2) ş̧eklinde iki gruba ayrıldı. Tüm veriler istatistiksel olarak karşılaştırıldı.

Bulgular: Tam kan sayımındaki birçok inflamatuvar ve trombotik aktivasyon belirtecinin, kontrol grubuna göre tedavi öncesi hasta grubunda artmış olduğu, tedavi sonrasında ise bu değerlerin çoğunun sağlıklı bireylerin değerlerine yaklaştığı gözlendi. Hastaların tedavi öncesi ve tedavi sonrası verileri kendi içlerinde karşılaştırıldığında; nötrofil ve platelet sayıları ve nötrofil-monosit oranı tedaviden sonra azaldığı ve istatistiksel olarak anlamlı fark olduğu tespit edildi. Tedavi gereksinim süresine göre belirlenen iki grubun tedavi öncesi değerleri karşılaştırıldığında, grup-2'deki hastalarda eozinofilbazofil oranı (EBO) değerinin anlamlı olarak yüksek olduğu belirlendi. Tedavi öncesine göre tedavi sonrasında; grup-1'deki hastaların platelet sayısının azaldığı, eozinofil-lenfosit oranı ve eozinofil-nötrofil oranı değerlerinin arttığı; grup-2'deki hastaların platelet, nötrofil sayıları ve EBO değerlerinin azaldığı, ortalama platelet hacmi (MPV) ve platelet dağılım genişliği (PDW) değerlerinin ise arttığı görüldü.

Sonuç: Omalizumab tedavisinin KSÜ'lü hastalarda, tam kan sayımında yer alan birçok inflamatuvar ve trombotik aktivasyon belirtecini azalttı̆̆ı yönünde olumlu etkileri olduğu belirlendi. EBO yükseliğinin, KSÜ’lü hastaların daha uzun süre omalizumab tedavisine gereksinim duyacağını öngören bir biyobelirteç olabileceği düşünüldü. Ayrıca, uzun süre tedavi gereksinimi olan hastaların Omalizumab tedavisi sırasında MPV ve PDW değerlerinin arttığının belirlenmesi, bu hastaların trombotik aktivasyon belirteçlerinin tedavi süresince daha yakından takip edilmesi gerektiği kanaatine varıldı.

Anahtar kelimeler: Kronik spontan ürtiker, Omalizumab, tam kan sayımı, biyobelirteç, trombotik aktivasyon.

\section{INTRODUCTION}

Urticaria is a mast cell-mediated disease, manifested by itchy and oedematous papules/plaques, angioedema due to the deep dermis or subcutis involvement, or both ${ }^{1}$. Its lifetime prevalence is around $8-22 \%$. Approximately half of the cases are accompanied by angioedema. It is called "acute urticaria" if the urticaria has been present for less than 6 weeks, and "chronic urticaria" for 6 weeks or more. The etiology of $50 \%$ of cases with chronic spontaneous urticaria (CSU) is unknown ${ }^{1,2}$. The pathogenesis of chronic urticaria is complex and has not been fully elucidated. Acute urticaria may have an allergic basis, but CSU usually does not have an allergic basis ${ }^{2}$. Urticaria is defined as a mast cellmediated disease ${ }^{1}$. Mediators and cytokines such as platelet-activating factor, mainly histamine, from mast cells in the tissue, basophils in the blood are released through the immune or non-immune mechanism. As a result, urticaria develops with vasodilation, increased permeability, plasma extravasation, accumulation of inflammatory cells, and sensory nerve activation ${ }^{3,4}$. Various mechanisms, such as autoimmunity, inflammation, and clotting, are thought to play a role in the pathogenesis of chronic urticaria ${ }^{5}$.

Omalizumab is a recombinant humanized monoclonal IgG antibody developed against IgE. This drug, which was first approved for use in treatment-resistant allergic asthma, was approved for use in patients with CSU in 20146. Omalizumab is an effective and reliable secondline treatment agent approved for CSU patients over 12 years of age, whose symptoms persist despite high-dose $\mathrm{H} 1$ antihistamine therapy, and is recommended for combined use $e^{1,7}$. In the treatment of CSU, it is recommended to use Omalizumab at a dose of $300 \mathrm{mg} / \mathrm{month}$ for 6 months. Clinical improvement may take up to 1 week after the first injection or 4 weeks. This drug is effective in more than $80 \%$ of patients. However, it is not a curative treatment agent. A relapse may occur within 10 weeks of 
discontinuation of treatment. In case of relapse, it can be used again without losing efficacy ${ }^{1}$. In $90 \%$ of patients who have started Omalizumab again, the disease can be controlled within the first 4 weeks ${ }^{8}$.

The complete blood count (CBC) is the most commonly used routine blood test that provides basic hematological measurements. The main assay recommended in the guidelines for chronic urticaria is CBC. In chronic urticaria; $\mathrm{CBC}$, erythrocyte sedimentation rate, and Creactive protein (CRP) tests are recommended at the stage of diagnosis, whereas in acute urticaria, the routine examination is not recommended 1 . So we should be able to evaluate the CBC test very well. Numerical measurement of blood cells is obtained with CBC examination and proportionate can be made based on these measurements. It is reported that the change in the numerical values and rates of blood cells is associated with increased inflammation and thrombotic risk.

This study aims to evaluate the effect of the drug on $\mathrm{CBC}$ parameters in patients with chronic spontaneous urticaria (CSU) treated with Omalizumab and to identify biomarkers that can help predict the duration of treatment requirement.

\section{METHODS}

Our study is a retrospective study. It was approved by the Ethics Committee of Hatay Mustafa Kemal University Faculty of Medicine with the 2018/49-56 approval code. A total of 100 people, including 66 patients who applied to the Dermatology clinic between 2014 and 2018, who received $300 \mathrm{mg} / \mathrm{month}$ subcutaneous Omalizumab treatment with the diagnosis of CSU, and 34 individuals constituting the healthy control group were included in the study. The demographic information, treatment responses, and duration of the patients were obtained from the records of our clinic. Within the last 1 month; patients with systemic steroids and immunosuppressive agents, patients with additional chronic diseases, patients with additional dermatological diseases, patients unresponsive to Omalizumab treatment, pregnant women, and patients under 18 years of age were excluded from the study.

In this study, the numbers and ratios of cells in the CBC of the control group and all patients with CSU were recorded before and after the 12th week of Omalizumab treatment. In addition, patients with CSU according to the Omalizumab treatment requirement; were divided into two groups as those who recovered in a short time ( $\leq 6$ months) (group- 1 ) and those who need longer treatment ( $>6$ months) (group-2).

$\mathrm{CBC}$ measurements were done using a complete blood count device (Mindray BC 6800-China). We recorded the neutrophil, lymphocyte, monocyte, eosinophil, basophil, platelet counts, red cell distribution width (RDW), mean platelet volume (MPV), platelet distribution width (PDW), neutrophil-lymphocyte ratio (NLR), eosinophil-lymphocyte ratio (ELR), eosinophil-neutrophil ratio (ENR), eosinophilbasophil ratio (EBR), platelet-lymphocyte ratio (PLR), platelet-neutrophil ratio (PNR), lymphocyte-monocyte ratio (LMR) and neutrophil-monocyte ratio (NMR) for all participants.

The numbers and ratios of cells in the CBC before and after Omalizumab treatment of the whole patient group and the data of the healthy control group were compared statistically. In addition, the values of patients who recovered in a short period and those who need long periods of treatment and the values of the healthy control group were compared statistically. IBM SPSS Statistics 21.0 software program was used for statistical analysis of the data. Relationships between categorical variables were analyzed by the Pearson chisquare test for continuous variables with the 
Kolmogorov Smirnov test. The student t test was used to compare the averages between the groups. In addition, the data were analyzed using The Wilcoxon Signed Ranks Test was used to compare peer groups that were not in compliance with normal distribution and Mann Whitney U tests. $p<0.05$ was considered significant. Lack of long-term data, lack of urticaria activity score, and a low number of patients are the limitations of our study.

\section{RESULTS}

One hundred people were included in our study, 66 (39 female, 27 male) CSU patients, and 34 (16 female, 18 male) healthy individuals. The average age of patients with CSU was $43.53 \pm 10.06$ years in women, $49 \pm 11.71$ years in men, total $\operatorname{IgE}$ $293.87 \pm 371.87 \mathrm{kU} / \mathrm{L}$, disease duration was 7.13 \pm 4.91 years. The age $(p=0.870)$ and gender $(p=0.252)$ of the patient and control groups were similar.

When the blood values of patients with CSU were compared before the Omalizumab treatment and the values of the control group; there was a statistically significant difference in many parameters between the two groups (Table I). Blood neutrophil ( $p=0.001)$, monocyte $(p=0.011)$, platelet $(\mathrm{p}=0.001)$ numbers, MPV $(\mathrm{p}=0.023)$, CRP $(p=0.001), \operatorname{NLR}(p=0.012), \operatorname{EBR}(p=0.017)$, PLR $(p=0.031)$ values were higher in patients in the patient group than in healthy individuals. In contrast, blood basophil count $(\mathrm{p}=0.001)$, RDW $(\mathrm{p}=0.014)$, PDW $(\mathrm{p}=0.001)$ and ENR $(\mathrm{p}=0.032)$ values were lower in the patient group than in the control group.

When the blood values of patients with CSU after 12 weeks of Omalizumab treatment were compared with the blood values of the control group; after Omalizumab treatment, the patients' blood monocyte $(p=0.035)$, platelet $(p=0.016)$ numbers and MPV ( $p=0.027)$ values were higher in individuals in the patient group than healthy individuals. In contrast, blood basophil count $(\mathrm{p}=0.001)$, RDW ( $\mathrm{p}=0.007)$, and PDW ( $\mathrm{p}=0.001)$ values were lower in the patient group than in the control group. In addition, even though EBR decreased significantly after treatment, it was still significantly higher than healthy individuals $(\mathrm{p}=0.029)$. It was determined that neutrophil count and NLR, ENR, PLR values approached control group values in patients receiving Omalizumab treatment, and there was no statistically significant difference (Figure 1, Table I).

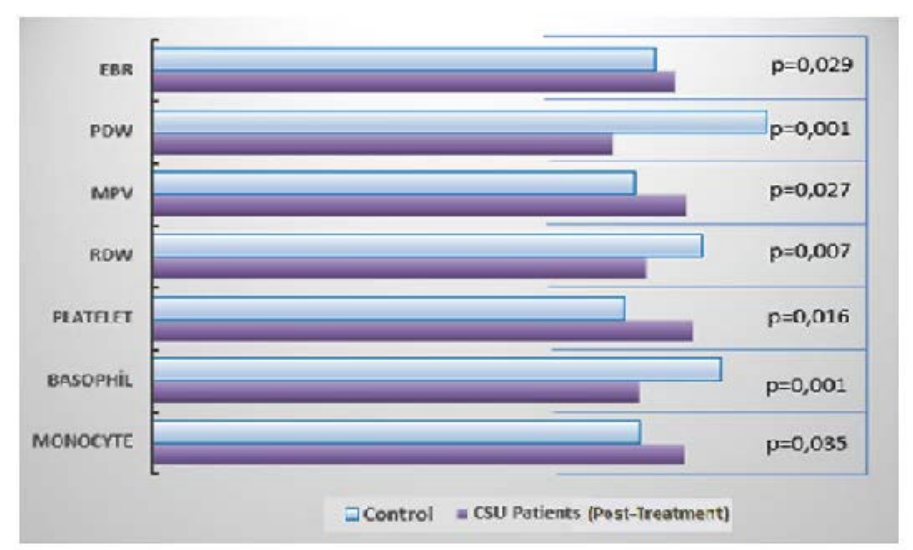

Figure 1. The statistically different parameters and values reached while comparing the post-treatment condition of CSU patients receiving Omalizumab treatment and the control group. T-score graph is given in addition to standardized Zscores when the units of the parameters exhibit difference.

When the pre-treatment and post-treatment data of the patients are compared within themselves; neutrophil $(\mathrm{p}=0.001)$, platelet $(\mathrm{p}=0.001)$ numbers and NMR $(p=0.036)$ decreased after treatment and there was a statistically significant difference (Figure 2, Table I).

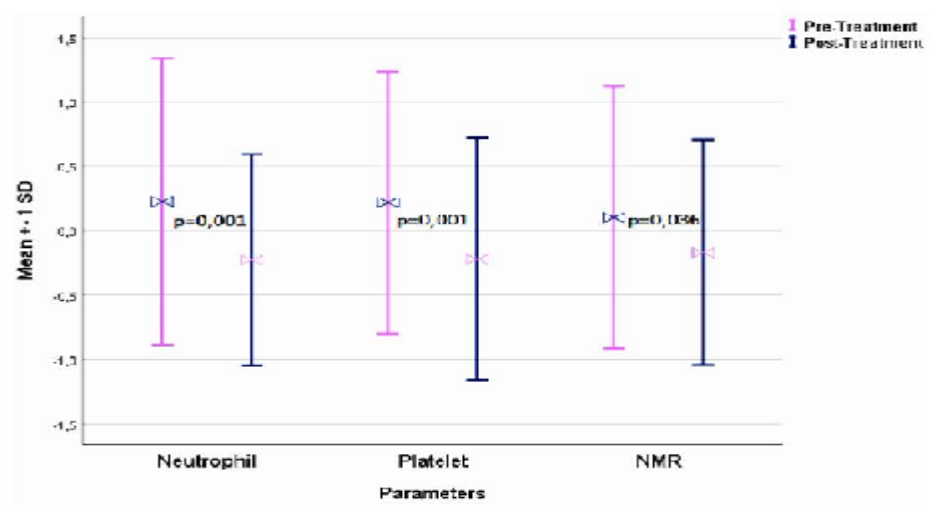

Figure 2. The statistically different parameters and values reached while comparing the CSU patients before and after Omalizumab treatment. Standardized Z-score graph is given when the units of the parameters exhibit difference. 
Table I: Comparison of the CBC parameters of CSU patients before and after the Omalizumab treatment and the control group.

\begin{tabular}{|c|c|c|c|c|c|c|c|}
\hline \multirow{2}{*}{ Parameters } & \multirow{2}{*}{ Normal Range } & \multirow{2}{*}{$\begin{array}{l}\text { Controls }(n=34) \\
\text { mean (median) }\end{array}$} & \multicolumn{2}{|c|}{ CSU patients $(n=66)$} & \multirow{2}{*}{$\begin{array}{c}\text { Pre-treatment } \\
\text { vs } \\
\text { Control } \\
\text { p }\end{array}$} & \multirow{2}{*}{$\begin{array}{c}\text { Post- } \\
\text { treatment } \\
\text { vs } \\
\text { Control } \\
\text { p }\end{array}$} & \multirow{2}{*}{\begin{tabular}{|} 
Pre-treatment \\
vs \\
Post- \\
Treatment \\
p
\end{tabular}} \\
\hline & & & $\begin{array}{l}\text { Pre-treatment } \\
\text { mean (median) }\end{array}$ & $\begin{array}{l}\text { Post-treatment } \\
\text { mean (median) }\end{array}$ & & & \\
\hline $\begin{array}{c}\text { Neutrophil } \\
\left(10^{3} / \mu \mathrm{l}\right)\end{array}$ & $2-7$ & $3,79(3,77)$ & $5,44(4,78)$ & $4,52(4,37)$ & 0.001 & $0.067^{*}$ & 0.001 \\
\hline $\begin{array}{c}\text { Lymphocyte } \\
\left(10^{3} / \mu \mathrm{l}\right)\end{array}$ & $1-4,8$ & $2,26(2,20)$ & $2,48(2,46)$ & $2,35(2,31)$ & 0.068 & $0.708^{*}$ & 0.074 \\
\hline $\begin{array}{c}\text { Monocyte } \\
\left(10^{3} / \mu \mathrm{l}\right)\end{array}$ & $0,12-1,2$ & $0,49(0,48)$ & $0,58(0,57)$ & $0,57(0,55)$ & 0.011 & 0.035 & 0.626 \\
\hline $\begin{array}{c}\text { Eosinophil } \\
\left(10^{3} / \mu \mathrm{l}\right)\end{array}$ & $0-0,7$ & $0,21(0,16)$ & $0,2(0,15)$ & $0,23(0,16)$ & 0.659 & 0.734 & $0.875^{* *}$ \\
\hline $\begin{array}{l}\text { Basophil } \\
\left(10^{3} / \mu l\right)\end{array}$ & $0-0,2$ & $0,05(0,05)$ & $0,03(0,02)$ & $0,03(0,03)$ & 0.001 & $0.001^{*}$ & 0.334 \\
\hline $\begin{array}{l}\text { Platelet } \\
\left(10^{3} / \mu \mathrm{l}\right)\end{array}$ & $150-400$ & $237,26(231,50)$ & $297,95(290,50)$ & $267,79(262,50)$ & 0.001 & 0.016 & 0.001 \\
\hline RDW (\%) & $11-16$ & $14,19(14,15)$ & $13,52(13,40)$ & $13,62(13,25)$ & 0.014 & $0.007^{*}$ & 0.761 \\
\hline MPV (fl) & $6,5-12$ & $9,20(9,11)$ & $9,92(10,00)$ & $9,94(10,05)$ & 0.023 & 0.027 & 0.931 \\
\hline PDW (\%) & $15-17$ & $16,81(16,70)$ & $12,04(11,80)$ & $12,51(12,05)$ & 0.001 & 0.001 & 0.158 \\
\hline NLR & & $1,75(1,58)$ & $2,44(2,02)$ & $2,11(1,84)$ & $0.012 *$ & $0.203^{*}$ & 0.092 \\
\hline ELR & & $0,09(0,07)$ & $0,08(0,06)$ & $0,11(0,07)$ & $0.266^{*}$ & $0.445^{*}$ & 0.191 \\
\hline ENR & & $0,06(0,04)$ & $0,05(0,03)$ & $0,06(0,04)$ & $0.032 *$ & $0.153^{*}$ & 0.299 \\
\hline EBR & & $10,96(3,75)$ & $93,52(7,81)$ & $32,02(5,90)$ & $0.017^{*}$ & $0.029 *$ & $0.278^{* *}$ \\
\hline PLR & & $111,42(102,28)$ & $132,24(115,95)$ & $122,96(112,50)$ & $0.031^{*}$ & $0.150^{*}$ & 0.118 \\
\hline PNR & & $66,37(65,05)$ & $63,11(58,06)$ & $65,99(60,25)$ & $0.489^{*}$ & $0.861^{*}$ & 0.353 \\
\hline LMR & & $4,74(4,73)$ & $4,57(4,28)$ & $4,46(4,18)$ & 0.001* & 0.435 & 0.567 \\
\hline NMR & & $7,93(7,85)$ & $9,17(8,75)$ & $8,24(7,88)$ & $0.065^{*}$ & $0.588^{*}$ & $0.036^{* *}$ \\
\hline
\end{tabular}

Abbreviations: CSU, chronic spontaneous urticarial; RDW, red cell distribution width; MPV, mean platelet volume; PDW, platelet distribution width; NLR, neutrophillymphocyte ratio; ELR, eosinophil-lymphocyte ratio; ENR, eosinophil-neutrophil ratio; EBR, eosinophil-basophil ratio; PLR, platelet-lymphocyte ratio; PNR, platelet-neutrophil ratio; LMR, lymphocyte-monocyte ratio; NMR, neutrophil-monocyte ratio; vs, versus.

Values were expressed mean (median). *: Mann Whitney U tests, **: Wilcoxon Signed Rank Test others paired Student -t Test were performed. $p<0$.05 is defined statistically significant.

Note: P-values that are considered statistically significant are shown in boldface.

The average duration of the Omalizumab treatment requirement of individuals in the patient group was calculated as 6 months. Therefore, those who heal with Omalizumab treatment for 6 months and less; healing group in a short time (group-1), those requiring Omalizumab treatment for more than 6 months; those who need treatment for a long time (group-2) were grouped. CBC parameters and rates of both groups were compared with each other. When group-1 was compared before and after treatment, it was observed that the number of platelets decreased significantly after treatment $(p=0.001)$, ELR $(p=0.018)$ and ENR $(p=0.050)$ values increased significantly. When group2 is compared before and after treatment, it is detected that; platelet $(p=0.029)$ and neutrophil $(p=0.027)$ numbers and EBR (p=0.005) values decreased significantly after treatment, and MPV $(\mathrm{p}=0.028)$ and PDW ( $p=0.010)$ values increased significantly. When the pre-treatment data of group-1 and group- 2 were compared, the EBR value of group-2 was significantly higher $(p=0.014)$. When the post-treatment data of group-1 and group-2 were compared, there was no significant difference (Table II). 
Table II: Comparison of the CBC parameters of CSU patient groups determined according to the need for Omalizumab treatment before and after treatment.

\begin{tabular}{|c|c|c|c|c|c|c|c|c|}
\hline \multirow{3}{*}{ Parameters } & \multicolumn{4}{|c|}{ Recovery time } & \multirow{3}{*}{$\begin{array}{c}\text { Group-1 } \\
\text { Pre-treatment } \\
\text { vs } \\
\text { Post- } \\
\text { treatment } \\
\text { p } \\
\end{array}$} & \multirow{3}{*}{\begin{tabular}{|c|} 
Group-2 \\
Pre-treatment \\
vs \\
Post- \\
treatment \\
p
\end{tabular}} & \multirow{3}{*}{$\begin{array}{c}\text { Group-1 } \\
\text { vs } \\
\text { Group 2 } \\
\text { Pre-treatment } \\
\text { p }\end{array}$} & \multirow{3}{*}{$\begin{array}{c}\text { Group-1 } \\
\text { vs } \\
\text { Group } 2 \\
\text { Post- } \\
\text { treatmen } \\
\text { p }\end{array}$} \\
\hline & \multicolumn{2}{|c|}{$\begin{array}{c}\leq 6 \text { month } \\
(\text { Group-1) } \\
(n=38) \\
(F / M ; 23 / 15)\end{array}$} & \multicolumn{2}{|c|}{$\begin{array}{c}>6 \text { month } \\
(\text { Group-2) } \\
(n=28) \\
(F / M ; 16 / 12)\end{array}$} & & & & \\
\hline & $\begin{array}{l}\text { Pre- } \\
\text { treatment }\end{array}$ & $\begin{array}{l}\text { Post- } \\
\text { treatment }\end{array}$ & Pre-treatment & $\begin{array}{l}\text { Post- } \\
\text { treatment }\end{array}$ & & & & \\
\hline $\begin{array}{c}\text { Neutrophil } \\
\left(10^{3} / \mu l\right)\end{array}$ & $5,67(4,93)$ & $4,70(4,38)$ & $\begin{array}{c}5,12 \\
(4,66)\end{array}$ & $\begin{array}{c}4,26 \\
(4,21)\end{array}$ & $0.062^{* *}$ & 0.027 & $0.479^{*}$ & $0.395^{*}$ \\
\hline $\begin{array}{c}\text { Lymphocyte } \\
\left(10^{3} / \mu \mathrm{l}\right)\end{array}$ & $2,36(2,37)$ & $2,30(2,19)$ & $2,64(2,59)$ & $2,40(2,31)$ & 0.486 & 0.081 & 0.126 & $0.571^{*}$ \\
\hline $\begin{array}{c}\text { Monocyte } \\
\left(10^{3} / \mu \mathrm{l}\right)\end{array}$ & $0,56(0,53)$ & $0,57(0,56)$ & $0,595(0,59)$ & $0,55(0,55)$ & 0.7 & 0.153 & 0.542 & 0.681 \\
\hline $\begin{array}{c}\text { Eosinophil } \\
\left(10^{3} / \mu l\right)\end{array}$ & $0,18(0,14)$ & $0,26(0,16)$ & $0,21(0,18)$ & $0,18(0,14)$ & $0.146^{* *}$ & $0.130^{* *}$ & $0.253^{*}$ & $0.512^{*}$ \\
\hline $\begin{array}{l}\text { Basophil } \\
\left(10^{3} / \mu l\right)\end{array}$ & $0,03(0,02)$ & $0,03(0,03)$ & $\begin{array}{c}0,02 \\
(0,01)\end{array}$ & $0,029(0,03)$ & $0.538^{* *}$ & $0.223^{* *}$ & $0.204^{*}$ & $0.768^{*}$ \\
\hline Platelet $\left(10^{3} / \mu \mathrm{l}\right)$ & $\begin{array}{c}298,18 \\
(290,50) \\
\end{array}$ & $\begin{array}{c}262,05 \\
(254,00) \\
\end{array}$ & $297,64(301,50)$ & $\begin{array}{c}275,57 \\
(268,00) \\
\end{array}$ & 0.001 & 0.029 & 0.975 & 0.404 \\
\hline RDW (\%) & $13,65(13,30)$ & $13,67(13,25)$ & $13,35(13,40)$ & $13,53(13,3)$ & $0.694^{* *}$ & $0.609^{* *}$ & $0.781^{*}$ & $0.876^{*}$ \\
\hline MPV (fl) & $10,08(10,15)$ & $9,79(10,00)$ & $\begin{array}{c}9,69 \\
(9,75)\end{array}$ & $10,12(10,15)$ & $0.281^{* *}$ & 0.028 & 0.195 & $0.533^{*}$ \\
\hline PDW (\%) & $12,24(12,45)$ & $12,18(11,60)$ & $11,76(11,45)$ & $12,93(12,65)$ & 0.899 & $0.010^{* *}$ & $0.302^{*}$ & 0.290 \\
\hline NLR & $\begin{array}{c}2,72 \\
(2,07)\end{array}$ & $2,23(1,91)$ & $\begin{array}{c}2,05 \\
(1,75)\end{array}$ & $1,92(1,70)$ & $0.357^{* *}$ & $0.274^{* *}$ & $0.113^{*}$ & $0.132^{*}$ \\
\hline ELR & $0,07(0,06)$ & $0,12(0,71)$ & $0,08(0,07)$ & $0,08(0,64)$ & $0.018^{* *}$ & $0.151^{* *}$ & $0.484^{*}$ & $0.371^{*}$ \\
\hline ENR & $0,04(0,02)$ & $0,07(0,03)$ & $0,05(0,03)$ & $0,04(0,03)$ & $0.050^{* *}$ & $0.339^{* *}$ & $0.184^{*}$ & $0.716^{*}$ \\
\hline EBR & $10,91(5,68)$ & $11,36(5,52)$ & $205,63(10,37)$ & $60,04(6,26)$ & $0.106^{* *}$ & $0.005^{* *}$ & $0.014^{*}$ & $0.533^{*}$ \\
\hline PLR & $\begin{array}{c}139,62 \\
(119,31)\end{array}$ & $\begin{array}{c}123,96 \\
(111,67)\end{array}$ & $122,22(110,78)$ & $\begin{array}{c}121,61 \\
(112,68)\end{array}$ & $0.071^{* *}$ & $0.838^{* *}$ & $0.371^{*}$ & $0.948^{*}$ \\
\hline PNR & $61,39(57,09)$ & $62,44(57,22)$ & $65,44(58,51)$ & $70,78(63,12)$ & 0.78 & $0.151^{* *}$ & $0.568^{*}$ & $0.129^{*}$ \\
\hline LMR & $4,44(4,20)$ & $4,22(4,15)$ & $\begin{array}{c}4,73 \\
(4,46)\end{array}$ & $4,78(4,30)$ & 0.358 & $0.716^{* *}$ & 0.392 & $0.460^{*}$ \\
\hline NMR & $9,55(9,59)$ & $8,62(8,38)$ & $8,68(7,70)$ & $\begin{array}{c}7,70 \\
(7,53)\end{array}$ & 0.07 & $0.302^{* *}$ & 0.337 & $0.215^{*}$ \\
\hline
\end{tabular}

Abbreviations: CSU, chronic spontaneous urticarial; RDW, red cell distribution width; MPV, mean platelet volume; PDW, platelet distribution width; $N L R$, neutrophil-lymphocyte ratio; ELR, eosinophil-lymphocyte ratio; ENR, eosinophil-neutrophil ratio; EBR, eosinophil-basophil ratio; PLR, plateletlymphocyte ratio; PNR, platelet-neutrophil ratio; LMR, lymphocyte-monocyte ratio; NMR, neutrophil-monocyte ratio; F/M, female/male; vs,versus.

Values were expressed mean (median). *: Mann Whitney $U$ tests, ${ }^{* *}$ : Wilcoxon Signed Rank Test others paired Student - $t$ Test were performed. $p<0.05$ is defined statistically significant.

Note: P-values that are considered statistically significant are shown in boldface.

\section{DISCUSSION}

Various mechanism, such as autoimmunity, inflammation, and clotting, are thought to play a role in the pathogenesis of chronic urticaria ${ }^{5}$. An abnormality or presence of thrombosis is noted in the CSU, although it does not produce clinical findings ${ }^{4,9}$. The eosinophil, neutrophil, and lymphocyte count in peripheral blood have been reported to be normal in patients with urticaria. However, the function of neutrophils and lymphocytes in urticaria is still unclear ${ }^{2}$. 
Omalizumab is known to be an effective agent in the treatment of CSU. However, the mechanism of action is still uncertain ${ }^{5,6}$. By binding IgE in the circulation, it prevents the release of cytokine from mast cells and basophils and reduces the migration of immune cells ${ }^{10}$. It reduces and desensitizes FcERI levels on the surface of mast cells and basophils. It reduces the binding of IgE to FcERI. It reduces IgE synthesis from B lymphocytes, causing basopenia ${ }^{4,11}$. Triggers eosinophil apoptosis ${ }^{1,7}$. It has been shown that elevated plasma D-dimer levels decrease in patients with severe CSU after Omalizumab treatment ${ }^{5}$.

In recent years, it has been mentioned that CBC parameters can be evaluated as biomarkers in determining inflammation and thrombotic risk increase. In some diseases, NLR, NMR, ELR, ENR, EBR, LMR, PLR, and CRP are reported to be inflammatory markers, MPV and PDW (platelet activation indices) are reported to be inflammatory and platelet activation markers ${ }^{12-}$ 17.

Platelets are versatile cells involved in many pathophysiological processes such as blood clotting, homeostasis, thrombosis, atherosclerosis, autoimmune and inflammatory diseases $^{17}$. PDW shows the homogeneity of platelet dimensions. It shows increased PDW anisocytosis, which is associated with pseudopod formation ${ }^{18}$. MPV has been reported to be a potentially useful indicator of cardiovascular risk ${ }^{19}$. Increased MPV has been demonstrated in vascular diseases such as pulmonary thromboembolism ${ }^{16}$. MPV and PDW are platelet activation markers, indicating platelet production and platelets are active. Although contradictory MPV values have been reported in CSU patients, Kolkhir et all., analysed 151 studies and reported that the increase in CRP and MPV was significant in patients with CSU compared to healthy individuals ${ }^{20}$. Ertaş et all., reported that in patients with CSU, MPV was high and PDW was low in the pre-treatment period compared to healthy controls and that there was a statistically significant increase in MPV and PDW values after Omalizumab treatment ${ }^{21}$. Acer et al., found that the number of platelets decreased and MPV increased after 12 weeks of Omalizumab treatment compared to pretreatment in patients with CSU22. Önder et al., reported that there was no significant change in MPV values after Omalizumab treatment ${ }^{23}$.

In our study, patients with CSU had higher platelet count, MPV, and PDW values than healthy individuals, both before and after treatment. However, when the patient group was compared in terms of the pre and posttreatment period, it was found that the number of platelets decreased significantly after the treatment. In our study, it was seen that platelet levels decreased significantly after treatment compared to pre-treatment in all patients in group-1 and group-2 determined according to the recovery time. On the other hand, it was determined that MPV and PDW, which are among the markers of thrombotic activation, increased in spite of the decrease in the number of platelets after treatment with Omalizumab in group-2, which was in need of more treatment. Iribarren et all., reported an increased incidence of serious cardiovascular and cerebrovascular adverse events in asthmatic patients receiving Omalizumab therapy ${ }^{24}$. This suggests that patients with CSU who need Omalizumab treatment for a long time should be followed up for thrombotic activation during Omalizumab treatment.

PLR has been reported to increase in the case of a large number of pro-inflammatory and prothrombotic diseases ${ }^{25}$. It has been demonstrated that the increase in PLR is associated with venous thrombosis ${ }^{26}$. Whereas PLR has been reported to be a potentially useful parameter to detect the risk of bleeding ${ }^{27}$. Acer et all., reported that PLR decreased significantly after treatment with Omalizumab in patients 
with $\mathrm{CSU}^{22}$. Ertaş et all., stated that the PLR value of patients with CSU was not different from the control group at the beginning and did not change significantly after Omalizumab treatment $^{21}$. In our study, it was determined that PLR was significantly higher before the treatment in the patient group compared to the control group and that the values approached the control group and there was no significant difference after the treatment.

Inflammation markers include neutrophils, lymphocytes, monocytes, eosinophils, and basophils ${ }^{28}$. Studies have reported that neutrophil count significantly decreased after 12 weeks of Omalizumab treatment ${ }^{22,23}$. Ertaş et all., Acer et all. and Önder et al., found a significant decrease in NLR after treatment compared to Omalizumab treatment ${ }^{21-23}$. In addition, Önder et all., reported that NMR decreased significantly after treatment, according to Omalizumab treatment ${ }^{23}$. In our study, similar to the data in the literature, neutrophil and monocyte counts were higher before treatment compared to the control group. In the patient group, a statistically significant decrease in neutrophil and NMR values was found after treatment with Omalizumab compared to pre-treatment. The decrease in NLR was not significant. While the PLR value was significantly higher in the pretreatment period compared to the control group, there was no significant difference after the treatment.

One of the indicators of chronic inflammation is increased RDW. RDW indicates erythrocyte membrane deformability and changes in erythropoiesis $^{29}$. In our study, RDW was lower in patients with CSU both before and after Omalizumab treatment compared to the control group, and the difference was significant. It has been reported that the number of blood basophils decreases in patients with active CSU, and there is an inverse relationship between disease severity and basophil count. Basophils have shown to be higher in lesional skin than lesionless skin. The findings suggest that the cause of basopenia may depend on the uptake of basophils in the blood into the skin tissue. With Omalizumab treatment, it was determined that the blood basophil count increased in patients with CSU6,7. Acer et all., reported that basophil count increased with Omalizumab treatment, but this increase was not statistically significant. They also reported that the number of eosinophils increased after treatment ${ }^{22}$. In our study, blood basophil level was significantly lower than the control group before and after treatment. Acer et al., found a significant increase in the number of eosinophils after Omalizumab treatment compared to pretreatment ${ }^{22}$. In our study, no significant difference was found in comparisons in terms of variability in eosinophil count. ENR values were significantly lower in patients with CSU than healthy individuals. In those who recovered with $\leq 6$ months Omalizumab treatment, it was determined that ENR and ELR increased significantly after treatment compared to pretreatment. It was thought that the increase in ENR and ELR values may be related to the decrease in blood lymphocyte and neutrophil counts.

It has been reported that there is a significant relationship between the increase in EBR value and allergy, sinonasal polyp, and asthma ${ }^{15,30}$. In our study, in patients with CSU who needed long-term Omalizumab treatment, the EBR value was high and it was determined that the EBR value decreased after treatment in these patients. It was observed that the only statistically significant parameter between the two groups that improved with Omalizumab treatment in a short time and requiring longterm treatment was EBR.

In conclusion, when CBC parameters are evaluated as a whole, it has been determined that Omalizumab treatment has positive effects in patients with CSU that it reduces many 
inflammatory and thrombotic activation markers in CBC. It was thought that an increase in EBR may be a biomarker that predicts that patients with CSU will need Omalizumab treatment for a longer period. In addition, it was concluded that MPV and PDW values increased during, Omalizumab treatment of patients with long-term treatment needs, and that thrombotic activation markers of these patients should be followed more closely during the treatment. Our results show that large-scale research is needed, in which CBC parameters of CSU patients receiving Omalizumab therapy are followed for a long time.

Ethics Committee Approval: Our study is a retrospective study. It was approved by the Ethics Committee of Hatay Mustafa Kemal University Faculty of Medicine with the 2018/49-56 approval code.

Declaration of Conflicting Interests: The authors declare that they have no conflict of interest.

Financial Disclosure: No financial support was received.

\section{REFERENCES}

1. Goncu EK, Aktan S, Atakan N, et al. The Turkish Guideline for the Diagnosis and Management of Urticaria-2016. Turkderm- Arch Turk Dermatol Venerology. 2016; 50: 82-98.

2. Grattan CEH, Saini SS. Urticaria and Angioedema. In: Bolognia JL, Schaffer JV, Cerroni L et al. Dermatology 4th ed, Elsevier, Chine, 2018: 304-19.

3. Altman K, Chang C. Pathogenic intracellular and autoimmune mechanisms in urticaria and angioedema. Clin Rev Allergy Immunol. 2013; 45: 47-62.

4. Kaplan AP. Chronic Spontaneous Urticaria: Pathogenesis and Treatment Considerations. Allergy Asthma Immunol Res. 2017; 9: 477-82.

5. Asero R, Marzano AV, Ferrucci S, Cugno M. DDimer Plasma Levels Parallel the Clinical Response to Omalizumab in Patients with Severe Chronic
Spontaneous Urticaria. Int Arch Allergy Immunol. 2017; 172: 40-4.

6. Kaplan AP, Giménez-Arnau AM, Saini SS. Mechanisms of action that contribute to efficacy of omalizumab in chronic spontaneous urticaria. Allergy. 2017; 72: 519-33.

7. Saini SS, Bindslev-Jensen C, Maurer M, et al. Efficacy and safety of omalizumab in patients with chronic idiopathic/spontaneous urticaria who remain symptomatic on $\mathrm{H} 1$ antihistamines: a randomized, placebo-controlled study. J Invest Dermatol. 2015; 135: 67-75.

8. Metz M, Ohanyan T, Church MK, Maurer M. Retreatment with omalizumab results in rapid remission in chronic spontaneous and inducible urticaria. JAMA Dermatol. 2014; 150: 288-90.

9. Tedeschi A, Kolkhir P, Asero R, et al. Chronic urticaria and coagulation: pathophysiological and clinical aspects. Allergy. 2014; 69: 683-91.

10. Chandrashekar L, Rajappa M, Sundar I, et al. Platelet activation in chronic urticaria and its correlation with disease severity. Platelets. 2014; 25: 162-5.

11. Chang TW, Chen C, Lin C, et al. The potential pharmacologic mechanisms of omalizumab in patients with chronic spontaneous urticaria. J Allergy Clin Immunol. 2015; 135: 337-42.

12. Jiang Y, Zang M, Li S. Serum PLR and LMR in Behcet's disease: can they show the disease activity? Medicine (Baltimore). 2017; 96: e6981.

13. Shi G, Zhao JW, Ming L. Clinical significance of peripheral blood neutrophil-lymphocyte ratio and platelet-lymphocyte ratio in patients with asthma. Nan Fang Yi Ke Da Xue Xue Bao. 2017; 37: 84-8.

14. Brescia G, Barion U, Zanotti C, Parrino D, Marioni G. Pre- and postoperative blood neutrophil-tolymphocyte and eosinophil-to-lymphocyte ratios in patients with sinonasal polyps: A preliminary investigation. Allergy Asthma Proc. 2017; 38: 64-9.

15. Brescia G, Barion U, Zanotti C, et al. Blood eosinophil-to-basophil ratio in patients with sinonasal polyps: Does it have a clinical role? Ann Allergy Asthma Immunol. 2017; 119: 223-6. 
16. Ghaffari S, Parvizian N, Pourafkari L, et al. Prognostic value of platelet indices in patients with acute pulmonary thromboembolism. J Cardiovasc Thorac Res. 2020; 12: 56-62.

17. Xu XR, Zhang D, Oswald BE, et all. Platelets are versatile cells: New discoveries in hemostasis, thrombosis, immune responses, tumor metastasis and beyond. Crit Rev Clin Lab Sci. 2016; 53: 409-30.

18. Vagdatli E, Gounari E, Lazaridou E, et all. Platelet distribution width: a simple, practical and specific marker of activation of coagulation. Hippokratia. 2010; 14: 28.

19. Chu SG, Becker RC, Berger PB, et all. Mean platelet volume as a predictor of cardiovascular risk: a systematic review and meta-analysis. J Thromb Haemost. 2010; 8: 148-56.

20. Kolkhir P, André F, Church MK, Maurer M, Metz M. Potential blood biomarkers in chronic spontaneous urticaria. Clin Exp Allergy. 2017; 47: 19-36.

21. Ertaş R, Özyurt K, Karakükçü Ç, et all. Evaluation of platelet parameters and neutrophil/lympocyte ratio during omalizumab treatment in patients with severe chronic spontaneous urticaria. Turk J Med Sci. 2018; 48: 1255-62.

22. Acer E, Kaya Erdogan H, Yuksel Canakcı N, Saracoglu ZN. The effect of omalizumab on hematological and inflammatory parameters in patients with chronic spontaneous urticaria. Cutan Ocul Toxicol. 2019; 38: 5-8.

23. Önder S, Ozturk M. How does omalizumab affect the immunoinflammatory response in patients with chronic spontaneous urticaria? Cutan Ocul Toxicol. 2020; 39: 31-5.

24. Iribarren C, Rahmaoui A, Long AA, et all. Cardiovascular and cerebrovascular events among patients receiving omalizumab: Results from EXCELS, a prospective cohort study in moderate to severe asthma. J Allergy Clin Immunol. 2017; 139: 1489-95.

25. Balta S, Demirkol S, Kucuk U. The platelet lymphocyte ratio may be useful inflammatory indicator in clinical practice. Hemodial Int. 2013; 17: 668-9.

26. Artoni A, Abbattista $M$, Bucciarelli $P$, et all. Platelet to lymphocyte ratio and neutrophil to lymphocyte ratio as risk factors for venous thrombosis. Clin Appl Thromb Hemost. 2018; 24: 808-14.

27. Cosansu K, Ureyen CM, Kılıc H, et all. New Uses of Platelet-Lymphocyte Ratio for Bleeding Risk Stratification in Patients with Nonvalvular Atrial Fibrillation: A Pilot Study. Dicle Med J. 2020; 47: 2433.

28. Germolec DR, Shipkowski KA, Frawley RP, Evans E. Markers of Inflammation. Methods Mol Biol. 2018; 1803: 57-79.

29. Tertemiz KC, Ozgen Alpaydın A, Sevinc C, et all. Could "red cell distribution width" predict COPD severity? Rev Port Pneumol. 2006; 22: 196-201.

30. Xiong W, Xu M, Zhao Y, et all. Can we predict the prognosis of COPD with a routine blood test? Int J Chron Obstruct Pulmon Dis. 2017; 12: 615-25. 